\title{
OPTIMIZATION OF FINANCES INTO REGIONAL ENERGY ${ }^{1}$
}

The development of modern Russian energy collides with the need for major investments in the modernization and renewal of generation and transmission capacity. In terms of attracting sufficient financial resources and find ways to increase, energy sector profitability and investment attractiveness of particular importance is the problem of investment financing optimizing aimed at minimizing the cost of financing while maintaining financial stability of the power companies and the goals and objectives of Russian energy system long-term development. The article discusses the problem of investment projects financing in power generation from the point of view of the need to achieve optimal investment budget. Presents the author's approach to the investment financing optimization of power generation company that will achieve the minimum cost of resources involved, taking into account the impact of the funding structure for the power generating company financial sustainability. The developed model is applied to the problem of investment budget optimiz-

\footnotetext{
${ }^{1}$ @ Domnikov Yu., Khodorovsky M. J., Khomenko P. M. Text. 2014.
} 
ing, for example, regional power generating company. The results can improve the efficiency of investment in energy, sustainable and competitive development of regional energy systems.

Keywords: investments, power generation company, financial sustainability, debt financing, optimization model

In the context of the integration of Russia into the world economy, one of the most important problems facing the energy is the need to attract significant investments in the sector. The reasons for this problem are the high depreciation of fixed assets in the energy sector, which is in the segment of power output $-60 \%$, the production of heat $-80 \%$, long-term operation of power as well as high capital measures on construction, reconstruction and modernization of production facilities in the energy sector [1]. Therefore, improving the efficiency and reliability of the energy, competitiveness faced with the need to develop a mechanism for attracting investment in the energy sector. These problems are relevant to regional power generation.

Power generation, including the production of electricity and heat, is the backbone of modern energy industry and experiences common to system problems, including associated with the need to increase investment potential.

Power generation company investment program financing, raising funds from various sources. Effective attracting investment involves the formation of such a financing structure of the investment budget, which can be reached with the minimum average cost of financial resources, in compliance with the conditions of the volume of attracted resources investment needs and financial stability criteria power generating company.

Problem of optimization of the financing structure of the companies paid attention to the fundamental works of leading foreign and domestic scholars, such as W. F. Sharpe, G. J. Alexander, J. V. Bailey [4], Birghem E., Erhard M. [5], Blank I. [6]. Based on the research in this area, and given the specific features of the energy generating industry, a model of optimizing the investment program financing power generation company.

Research the basic parameters of the optimization model. Assume power generating company implements investment projects $i$. These projects are funded from $j$ sources of investment financing power generation company. Each funding source can be classified into the category of their own or borrowed funds. We denote this as $a$ sign of $k$.

Power generating company implements its activities in projects of varying size of the budget, the riskiness, the value and liquidity of required collaterals and other factors affecting the value of the resources of investment financing. I for each of the investment projects financed from the $j$-th source may determine the amount of financial resources $c_{i i j}$. Each investment project can determine the level of the cost of resources involved, in which the investment project becomes uneconomical due to excess expenditure over the discounted present value on the investment project.

Optimization of investment sources involves consideration of the effect on the financial structure of financing resistance power generating company. Importance factor of financial stability gains in the face of rising debt burden on the regional generating companies, causing the reduction of their ability to pay. Default TGC-2, was the cause of the restructuring of the bond issue in August 2013, was due to high costs, low profitability of the energy business and significant debt burden on the company, hence the need to factor in the financial stability in attracting financing activities of energy companies.

Assessing the impact of the financing structure of investments on the financial stability of the power generating company associated with the introduction of coefficient optimization model, is an integral component of financial stability power generating company (1). The assessment was based on the parameters of the model, empirical data on the Russian energy sector companies [2].

$$
\begin{aligned}
G= & 0,627 \times F_{1}+0,796 \times F_{2}+0,410 \times F_{3}+ \\
& +0,428 \times F_{4}+0,316 \times F_{5}+0,282 \times F_{6},
\end{aligned}
$$

where $G$ - an integral index of the financial sustainability power generating company, $F_{1}$ - leverage levels, $F_{2}$ - interest coverage ratio, $F_{3}$ - working capital ratio of its own sources of funding, $F_{4}-$ cash ratio, $F_{5}-$ cost-benefit ratio of own funds, $F_{6}$ - return on EBITDA.

During the investigation it was found that the effect of leverage on the financial stability of sources generating company, is not linear (Fig. 1). At some stage, the increase in leverage funding sources in the structure leads to a positive impact on financial stability due to increased efficiency of financial management and the effect of leverage. Further growth of leverage in the structure of financing leads to a negative impact on the financial stability of the power generating company due to lower growth of autonomy and the risks associated with its borrowings. In order to address the impact of the funding structure for financial sta- 


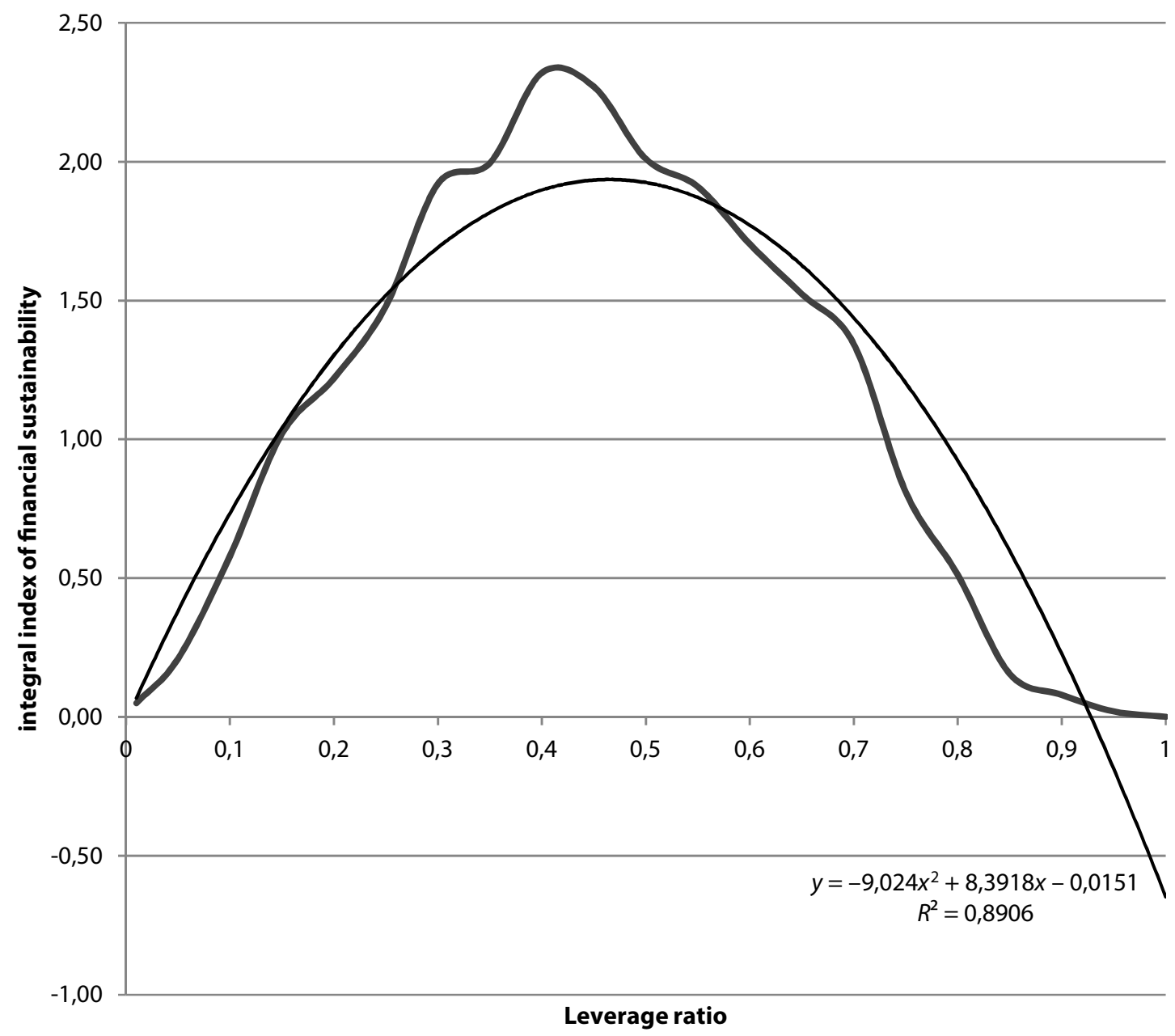

Fig. 1. Dependence of the power generation company financial stability and leverage ratio

bility in the nonlinear optimization model introduced restriction quantitatively determines the dependence of the stability of the financial leverage sources.

Let $x_{j}$ - the proportion of funds raised from the $j$-th source at a given level of funding cost in total resources involved.

The objective function minimizes the cost involved resources to finance investment programs (2):

$$
F(w)=\sum_{j} \sum_{k} r_{j k} \times x_{j k} \rightarrow \min ,
$$

where $r_{i k}-$ cost of the resources involved power generating company of the $j$-th source $k$-type, $x_{j k}$ - share of the $j$-th source $k$-type investment program in the budget.

Optimization model will include the following balances and limitations:

1. Restrictions on the cost of financing the investment program (3)

$$
\sum_{i} \sum_{j} \sum_{k} c_{i j} \times x_{j k} \leq b_{i}
$$

where $b_{i}-$ the maximum cost of the resources involved to finance the $i$-th source, $c_{i j}-$ cost of funds raised from the $i$-th source of equity financing for the $j$-th project.

2. Budget balance of the investment program (4)

$$
\sum_{i} x_{j}=1 .
$$

3. Non-linear constraint on the ratio of debt to equity (5)

$$
\sum_{i} \sum_{j} \sum_{k}\left(a_{i j} \times x_{j k}+d_{i j} \times x_{j k}^{2}+e_{i j}\right) \leq G_{i},
$$

where $G$ - an integral index of financial sustainability power generating company, $a_{i j}, d_{i j}, e_{i j}-$ empirical coefficients of the model.

4. Restrictions on the amount of debt (6)

$$
S_{i \min } \leq \sum_{i=k} x_{i} \leq S_{i \max },
$$

where $S_{i \min }$ - the lower limit value of debt, $S_{i \max }-$ the upper limit on the amount of borrowed funds.

5. Limits of the investment project (7)

$$
0 \leq x_{j} \leq 1
$$

Optimization model of power generating company investment budget structure in a formal statement would look like (8): 


$$
\left\{\begin{array}{l}
F(w)=\sum_{j} \sum_{k} r_{j k} \times x_{j k} \rightarrow \min \\
\sum_{i} \sum_{j} \sum_{k} c_{i j} \times x_{j k} \leq b_{i} \\
\sum_{i} \sum_{j} \sum_{k}\left(a_{i j} \times x_{j k}+d_{i j} \times x_{j k}^{2}+e_{i j}\right) \geq G_{i} \\
S_{i \min } \leq \sum_{i=k} x_{i} \leq S_{i \max } \\
\sum_{i} x_{j}=1 \\
0 \leq x_{j} \leq 1 \\
i=\overline{1, m}, j=\overline{1, n} .
\end{array}\right.
$$

Optimization model of the investment budget power generating company is nonlinear optimization problem, since the system of constraints includes a nonlinear component that determines the effect of financial leverage on the financial stability of the power generating company.

Based on the proposed optimization model solved the problem of optimizing the investment budget, for example, regional power generating company TGC-9. Sources of investment financing power generation company can be classified on their own, borrowed and borrowed funds (Fig. 2). Own funds include cumulative retained earnings and reserves of the enterprise. Funding received from the additional issue of ordinary and preference shares, budget form attracted fund- ing sources. Loans - are financial resources received on terms of payment, maturity, repayment to creditors. These include bank loans, investment loans, project financing funds, leasing, bonds and securitization. To some extent, perhaps in a category including factoring, forfeiting and sustainable payable with long periods of turnover, but their share in the structure of funding, especially capital investments will be small because of the short maturity debt.

For each funding source is possible to determine the level of indicative value, which is determined by several factors. Estimated cost of financing through the issuance of common and preferred shares a dividend, the amount of which can be estimated from comparable industry companies. Coupon income will represent the value of bond financing, bank loans, investment loans, project finance and leasing, securitization - interest rates, general and administrative costs associated with funding.

Determination of the optimal funding sources of quantitative estimation of cost of resources involved for each funding source. Cost of financial resources is one of the determining factors for the formation of the optimal financing structure of the investment project. Significant structural factors in the formation of the financing structure are flexibility of control, risk, expected returns and

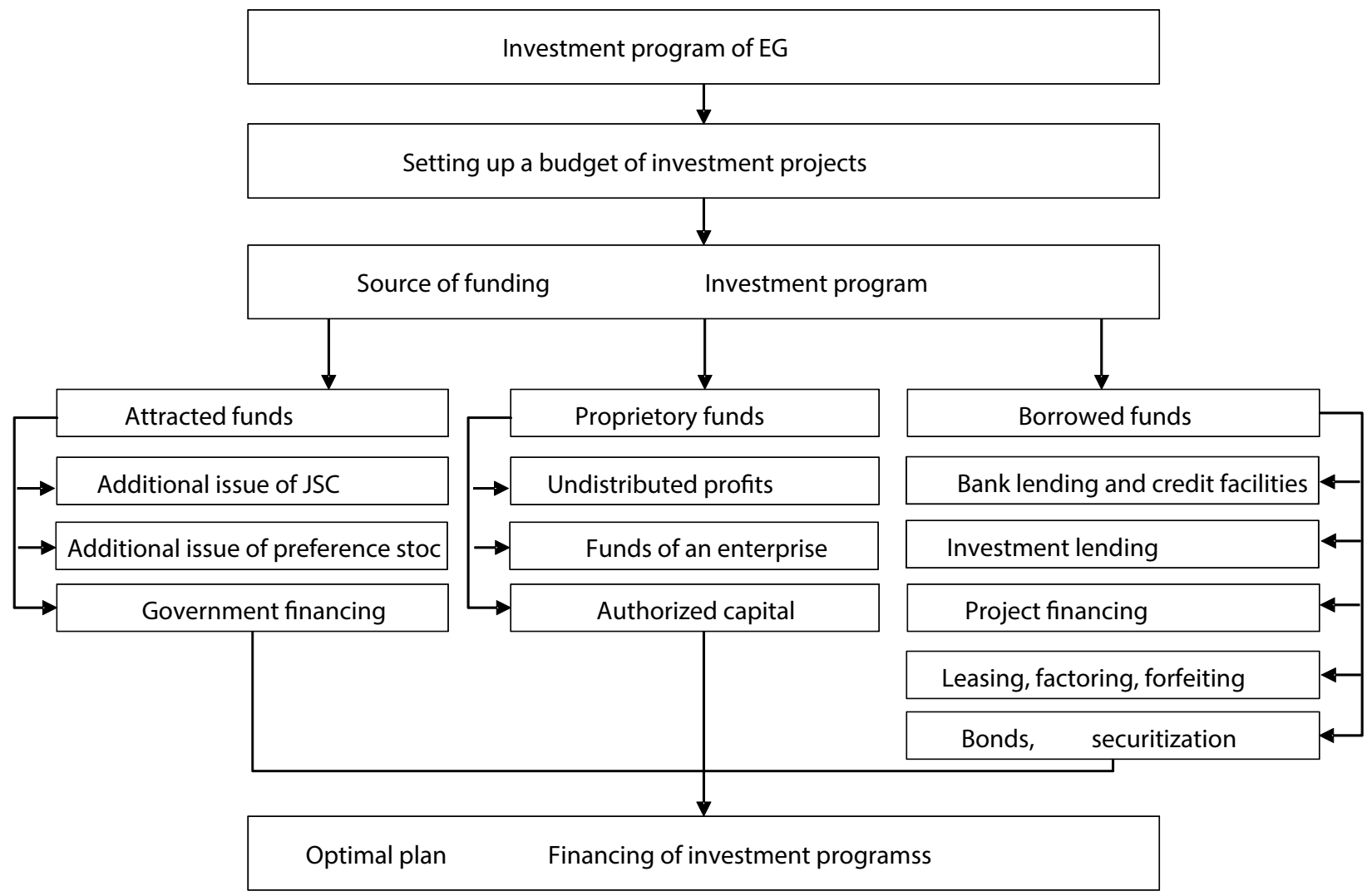

Fig. 2. Optimization mechanism of investment financing a power generation company 
volatility, the ability to maintain control of the business and the time of the operation [3].

According to the investment program of TGC-9 in the company implemented 11 investment projects [7]. Data on the name of projects, their content and the costs of implementation are presented in Table 1.

Forecasting of the cost of dividend payments in order to assess the cost of financing investments involved in the process of additional shares, carried out on the basis of statistics of dividends on ordinary shares major stock market participants belonging power generation sector.

Score coupon bond yields possible on the basis of statistical correlation value and volume of financing the investment program by ruble bond placements considering the industry average coupon and value of bonds outstanding. The raw data used for the calculation are given in Table 3.

Coupon average of $7.96 \%$ per annum, while the average yield on bonds with 5-year maturity of more than $8 \%$. Average amount of bonds outstanding is 4375 million. Thus, for the financing of the investment program placement issue of commercial papers. Consequently, as a source of investment financing power generation company may be indicative of exchange bonds issue worth 5 billion rubles with a yield of $8 \%$ per annum.

Rating interest rates on major credit products (banking and investment lending, leasing, other debt financing) was made on the basis of the CBR and the average indicators of risk of each project [9].

Calculated values of the model parameters optimization of financing investment projects from each source are presented in Table 4 . The model suggests the possibility of financing investment projects through an additional share issue $(j=1)$, bonds $(j=2)$, bank loans $(j=3)$, investment lending and project financing $(j=4)$ and leasing $(j=5)$.
Table 1

The investment program of TGC-9

\begin{tabular}{|l|c|}
\hline \multicolumn{1}{|c|}{ Investment project } & Budget, mln \\
\hline Reconstruction of Perm HPP-6 & 7429 \\
\hline Reconstruction of Perm HPP-9 & 7511 \\
\hline $\begin{array}{l}\text { Construction of the New-Bereznikovskaya } \\
\text { HPP }\end{array}$ & 10482 \\
\hline $\begin{array}{l}\text { Reconstruction Nizhneturinskaya GRES } \\
\text { power plant }\end{array}$ & 17000 \\
\hline Construction Novobogoslovskaya HPP & 10040 \\
\hline Construction of HPP Academic & 10565 \\
\hline
\end{tabular}

Table 2

Dividends generating companies

\begin{tabular}{|l|c|c|c|}
\hline \multirow{2}{*}{ Company name } & \multicolumn{3}{|c|}{ Dividends, \% } \\
\cline { 2 - 4 } & $\mathbf{2 0 0 9}$ & $\mathbf{2 0 1 0}$ & $\mathbf{2 0 1 1}$ \\
\hline RusHydro & 0 & 0,64 & 1,01 \\
\hline Inter RAO & 0 & 0,04 & 0 \\
\hline E.On Russia & 0 & 0 & 2,54 \\
\hline WGC-2 & 0 & 0,32 & 0,2 \\
\hline Enel WGC-5 & 0 & 0 & 0 \\
\hline Mosenergo & 0,4 & 0,75 & 1,84 \\
\hline Irkutskenergo & 1,1 & 0,55 & 0,71 \\
\hline
\end{tabular}

Bond yields territorial generating companies

\begin{tabular}{|c|c|c|c|c|}
\hline $\begin{array}{c}\text { Bond } \\
\text { issue }\end{array}$ & Maturity & Coupon & $\begin{array}{c}\text { Yield to } \\
\text { maturity }\end{array}$ & $\begin{array}{c}\text { Total } \\
\text { outstanding, } \\
\text { mln }\end{array}$ \\
\hline TGC-1-1 & 11.03 .2014 & 7,6 & 8,85 & 4000 \\
\hline TGC-1-2 & 01.07 .2014 & 6,7 & 8,19 & 5000 \\
\hline TGC-1-3 & 14.12 .2021 & 7,6 & 7,74 & 2000 \\
\hline TGC-1-4 & 14.02 .2022 & 7,6 & 7,74 & 2000 \\
\hline TGC-2-1 & 17.09 .2013 & 9 & 47,23 & 5000 \\
\hline TGC-5-1 & 06.10 .2017 & 8,75 & 10,15 & 5000 \\
\hline TGC-6-1 & 24.08 .2017 & 8,3 & 9,77 & 5000 \\
\hline TGC-9-1 & 07.08 .2017 & 8,1 & 10,35 & 7000 \\
\hline \multicolumn{2}{|r|}{ Avg.: } & 7,96 & 13,75 & 4375 \\
\hline
\end{tabular}

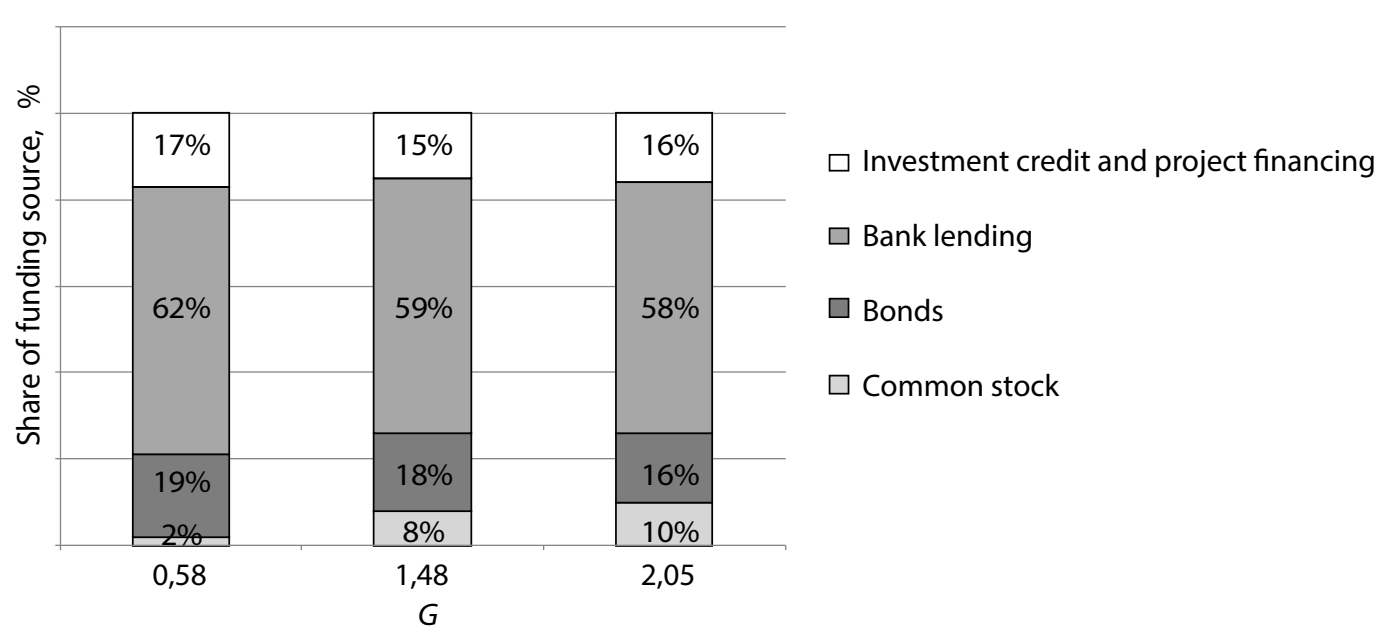

Fig. 3. The results of optimization of financing investment program TGC-9 for various parameters of financial stability 
Table 4

The financing investment projects cost from various sources

\begin{tabular}{|c|c|c|c|c|c|}
\hline \multirow{2}{*}{$i$} & \multicolumn{5}{|c|}{$j$} \\
\cline { 2 - 6 } & 1 & 2 & 3 & 4 & 5 \\
\hline 1 & 0,010 & 0,080 & 0,120 & 0,100 & 0,120 \\
\hline 2 & 0,010 & 0,090 & 0,125 & 0,150 & 0,131 \\
\hline 3 & 0,030 & 0,095 & 0,128 & 0,180 & 0,140 \\
\hline 4 & 0,020 & 0,105 & 0,130 & 0,122 & 0,148 \\
\hline 5 & 0,040 & 0,100 & 0,131 & 0,142 & 0,138 \\
\hline 6 & 0,040 & 0,101 & 0,128 & 0,140 & 0,140 \\
\hline
\end{tabular}

Table 5

Empirical evaluation of the model indicator of financial stability

\begin{tabular}{|c|c|c|c|c|c|c|}
\hline \multirow{2}{*}{$i$} & \multicolumn{3}{|c|}{$j$} & \multicolumn{3}{c|}{$G$} \\
\cline { 2 - 7 } & 1 & 2 & 3 & 1 & 2 & 3 \\
\hline 1 & $-8,207$ & 7,266 & $-0,004$ & 0,58 & 1,48 & 2,05 \\
\hline 2 & $-9,977$ & 7,675 & $-0,014$ & 0,58 & 1,48 & 2,05 \\
\hline 3 & $-9,500$ & 5,457 & $-0,014$ & 0,58 & 1,48 & 2,05 \\
\hline 4 & $-7,253$ & 7,225 & $-0,010$ & 0,58 & 1,48 & 2,05 \\
\hline 5 & $-7,237$ & 4,450 & $-0,012$ & 0,58 & 1,48 & 2,05 \\
\hline 6 & $-7,337$ & 6,732 & $-0,007$ & 0,58 & 1,48 & 2,05 \\
\hline
\end{tabular}

In assessing the relationship between the empirical parameters integral indicator of financial stability and a specific gravity of borrowed funds in the financing of the investment model was obtained nonlinear constraint presented in Table 5. In this work was carried out optimization of sources of investment financing for three differ- ent values of the coefficient of financial stability: not less than 0.58 , not less than 1.48 , not less than 2.05 .

By solving the optimization problem based on the model and the data in the table were obtained $1,4,5$ several optimal financing structures investment, based on the different values of the financial stability (Fig. 3).

Application of the proposed optimization model of financing the investment program power generating company, considered on the example of the subject of regional generation, allows us to solve a number of important challenges facing modern russian energy:

1. Ensure the effectiveness of the investment programs needed in a market economy and competition in the framework of regional and international energy market.

2. Ensure financial stability of the company, which is a necessary condition for sustainable development and conservation of solvency and capacity to attract funding.

3. Increase investment attractiveness of regional assets.

4. Meet the needs of industrial development by increasing the productive capacity of regional energy.

5. Improve the reliability of the regional power due to upgrade production facilities.

6. Create preconditions for the development of forms of "green" energy at the regional level, by the universality of the model and the possibility of applying for various forms of generation facilities.

\section{References}

1. Fedorov D. Finansirovanie modernizatsii rossiyskikh energoaktivov [Funding the modernization of Russian energy assets]. Available at: http://www.energoholding.gazprom.ru/files/

2. Domnikov A.Yu. (2008). Konkurentnoye razvitie sistemy kengeneratsii energii [Competitive development of cogeneration systems of energy]. Yekaterinburg, UGTU-UPI [Ural State Technical University], 364.

3. Kanke A. A., Koshevaya I. P. (2007). Analiz finansovo-khozyaystvennoy deyatelnosti predpriyatiya [Analysis of financial and economic activity of the enterprise] (2 ed. per. and added). Moscow, Forum, Infra-M, 288.

4. Sharpe W. F., Alexander G. J., Bailey J. V. (1997). Investitsii (per. s angl.)[Investments (translated from English)]. Moscow, Infra-M, 442.

5. Brigham Y., Ehrhardt M. (2009). Finansovyy menedzhment [Financial Management]. (10th ed.). Tr. from English, ed. Dorofeyev Ye.A. St. Petersburg, Piter, 960.

6. Blank I. A. (2004). Osnovy finansovogo menedzhmenta Tekst: $v 2$ t. [Fundamentals of Financial Management Text.: 2 Vol.] (2 ed. per. and added). Elga, Nick Center, 656.

7. Godovoy otchot za 2011 OAO “TGK-9" - 182 [Annual Report 2011 of JSC “TGC-9" - 182]. Official site of the JSC "TGC9". Available at: http://www.tgc9.ru/fileadmin/f/tgc9/ir/disclosure/anual_report/2011.pdf

8. Sheremet A. D., Negashev Ye. V. (2009). Metodika finansovogo analiza deyatelnosti kommercheskikh organizatsiy [Methodology of financial analysis of commercial organizations]. (2 ed. per. and added). Mocsow, Infra-M, 208.

9. Srednevzveshennyye protsenty stavki po kreditam, predostavlennym kreditnymi organizatsiyami fizicheskim litsam $i$ nefinansovym organizatsiyam, $v$ rublyakh [Weighted average interest rates on loans granted by credit institutions to individuals and non-financial institutions in rubles]. Official site of the Bank of Russia. Available at: http://www.cbr.ru/statistics/print.aspx?file=b_ sector/dii_rates_2-7.htm\&pid=cdps\&sid=ITM_60399 


\section{Information about the authors}

Domnikov Alexey Yuryevich (Yekaterinburg, Russia) - Doctor of Economics, Professor of the Banking Chair, Director of REC "INZHEK", Ural Federal University named after the first Russian President B. Yeltsin (19A, Mira st., Yekaterinburg, 620002, Russia, e-mail: domnikov@e1.ru).

Khodorovsky Mikhail Yakovlevich (Yekaterinburg, Russia) - Doctor of Economics, Professor, Head of the Banking Chair, Ural Federal University named after the first Russian President B. Yeltsin (19A, Mira st., Yekaterinburg, 620002, Russia, e-mail: office@sinara-group.com).

Khomenko Pavel Mikhaylovich (Yekaterinburg, Russia) — PhD Student of the Banking Chair, Ural Federal University named after the first Russian President B. Yeltsin (19A, Mira st., Yekaterinburg, 620002, Russia, e-mail: pavelkhom@gmail.com). 